\title{
IS WECHAT SOCIAL TECHNOLOGY FITTING TO A WECHAT BRAND GROUP?
}

\author{
Linwu Gu, Indiana University of Pennsylvania, lgu@iup.edu \\ Jianfeng Wang, Indiana University of Pennsylvania, jwang@iup.edu
}

\begin{abstract}
Social commerce platform provides a new way of information sharing for brand-customer interactions. As a social media and e-commerce platform, WeChat can be used for searching and providing product or service information among group members. This study mixes the social capital and task technology fit theories to study social commerce engagement, and the social and brand effects of WeChat on social commerce performance. Data of 95 WeChat users were collected from the online survey and analyzed using the PLS for path analysis and hypothesis test. The results reveal that the social technology fit is an effective mediator between brand trust and WeChat social commerce engagement. The low brand experience does not significantly moderate the relationship between social technology fit and social commerce engagement.
\end{abstract}

Keywords: Social Technology Fit; Social Commerce Engagement; WeChat Brand Group

\section{INTRODUCTION}

WeChat brand groups discuss not only fashions and brands but also group members' shopping experiences, reviews and referrals. For social media and technology adoption, social capital and task-technology fit are two of often-cited theories (Nahapiet \& Ghoshal, 1998; Goodhue \& Thompson, 1995). Zhang et al. (2017) note that brand group participation may be dependent on users' perception of technology fit. Bıçakcioğlu et al. (2018) find that consumers with a low brand experience opinion reduce their shopping behavior. Shen et al. (2019) define social commerce engagement as the extent to which people are willing to participate on a product or service in various types of social activities. This paper attempts to combine social capital and task technology fit theories to assess WeChat brand groups. We extend brand trust and social technology fit of Lu and Yang (2014) by adding the mediating role of social technology fit. The paper tests whether the low brand experience moderates social commerce behavior, and whether WeChat social-technology-fit can strengthen the relationships between brand trust and social commerce engagement (Figure 1).

\section{SOCIAL CAPITAL AND TASK TECHNOLOGY FIT THEORY}

The task-technology fit model is a commonly used theoretic base for assessing how information technology impacts individual user performance (Goodhue \& Thompson, 1995). The social capital theory is widely used for explaining and predicting social factors and social relationships (Nahapiet and Ghoshal, 1998). Social capital is defined and measured along structural, cognitive, and relational dimensions. The key constructs of social capital include shared language and codes, trust, shared information, and social ties. We define brand trust as relational social belief in WeChat brand group to connect group members with a brand. The task technology fit model does not address social factors while social capital theory does not examine technology feature. Any single theory of social commerce research lacks a clear prediction of the effects of social technology fit on social commerce engagement from a WeChat brand group's viewpoint. Therefore, we combine social capital theory and task technology fit model by adding social technology fit and brand trust in the research model. 


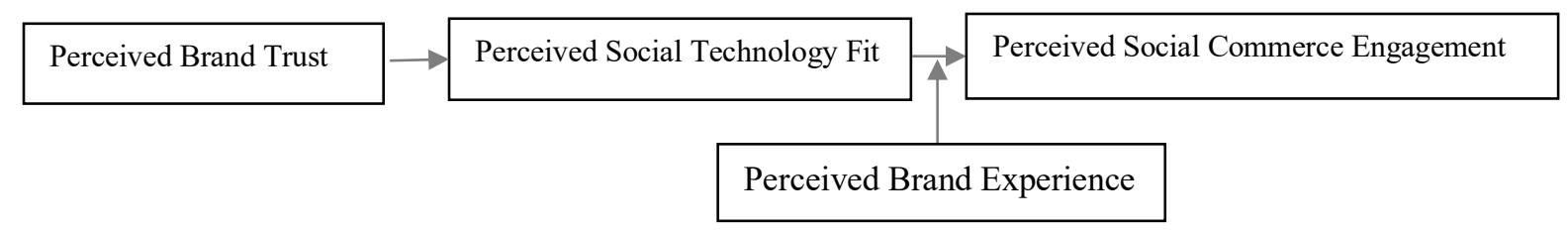

Figure 1. The Theory Model of Brand Groups' Social Technology Fit on Social Commerce Engagement

\section{RESEARCH MODEL}

This section introduces the theoretical framework and hypotheses developed to better understand the impacts of brand trust and social technology fit on WeChat social commerce engagement.

\section{Brand Trust}

Brand trust is important to social commerce engagement because first, brand trust reveals a consumer's positive expectation of products and brands (De Vries 2012); and second, brand trust indicates consumers' willingness to their belief in the brand (Chaudhuri \& Holbrook, 2001). Becerra and Badrinarayanan (2013) find brand trust increase the intention to purchase. Yang et al. (2013) have also found that product reviews about a brand influence social commerce performance. Zhang et al. (2017) note that when group members perceive high level of social technology fit, they would rely more on messages generated by the group. In this study, brand trust is defined as the degree of confidence on a brand. Brand trust among group members in WeChat brand group may be improved by social technology fit.

\section{Social Technology Fit}

With social networking features, WeChat provides platforms for messaging, texting, video-sharing, WeChat moments, mapping and localization, and WeChat Pay (Wang \& Gu 2017). Animesh et al. (2011) find that the social commerce environment facilitates customer to customer interactions by social media technologies. The task technology fit model is usually used for explaining and predicting individual performance from task technology adoption. Although it is an often-cited model for finding the relationship between technology utilization and individual performance, some researchers think the task technology fit model should incorporate social capital dimensions. Zhang et al. (2014) have concluded that perceived task technology fit can be linked to social networking performance, and social technology fit can be measured by the perceived impacts from user perceptions. Consequently, perceived social technology fit refers to the degree by which technology assists an individual in satisfying his or her social needs (Lu \& Yang 2014)

\section{Brand Experience}

Brand experience has been found to play an important role in social commerce engagement. Islan and Rahman (2017) have found that customer perceived enjoyment and cognition involvement toward a brand are associated with other consumers' reviews, purchases, and post-purchase behaviors. Brand experience is defined as consumers' behavioral responses induced through brand stimulants with individual consumer reactions (Brakus et al., 2009). Leslie et al. (2017) have shown that people with higher brand experience tend to be more knowledgeable, enthusiastic, and often more motivated than those with lower brand experience. When the degree of consumer brand experiences strengthens, customer satisfaction converts into customer purchase behavior. When consumers have brand experience, the effects of brand experience on intention to commerce engagement would be strengthened (Bıçakcığlu et al. 2018). Likewise, low brand experience is found to negatively impact shopping behavior (Ha \& Perks, 2005). Brand experience can provide useful theoretical lens for explaining the fundamental customer-brand relationships. Therefore, low brand experience is assumed to specifically moderate the relationships between social technology fit and social commerce engagement. 


\section{Issues in Information Systems}

Volume 20, Issue 3, pp. 158-164, 2019

\section{Social Commerce Engagement and WeChat Brand Groups}

WeChat brand groups provide forums for social interactions, such as information sharing, networking, and collaborating, to facilitate communications among group members. A WeChat group is not only a media excitement but also an established social commerce platform where group members can share information of buying or selling and use peer-to-peer payment through WeChat pay (Wang \& Gu, 2017).

Social commerce engagement is defined as users' generating content and sharing information, experiences, opinion, and knowledge about products or services with social commerce application (Zhang et al., 2019). Shen et al. (2019) define social commerce engagement as the behavior of employing technology in completing tasks. In the task technology fit model, social media technology utilization depends on the fit between the technology and the task it supports. Gu and Wang (2018) have found that perceived task technology fit model substantially influences IT-enabled collaboration to sell, buy, or swap on WeChat.

Brand trust has been found to be associated with the intention to purchase and support closer customer relationship in marketing (Tang et al, 2018). In this study, perceived social technology fit is defined as perceived usefulness in which the WeChat technology helps in performing the brand group activities. The reviews and discussions in WeChat by any practical brand group are the very useful sources for data collection to assess social commerce engagement. Since social commerce in WeChat is a sparsely researched area, this study examines the impact of brand trust and social technology fit on social commerce engagement. Therefore, we propose as following:

$\mathrm{H}_{1}$ : Perceived social technology fit mediates the relationship between perceived brand trust and perceived social commerce engagement

$\mathrm{H}_{2}$ : Perceived brand experience moderates the relationship between perceived social technology fit and perceived social commerce engagement

\section{RESEARCH METHODOLOGY}

The two hypotheses are tested using the structural equation modeling. In the following section we first describe survey instrument and specific measures used to assess the variables identified. Next, we explain the use of PLS as the method of data analysis, model reliability and validity. Finally, we analyze the structural model results.

\section{Survey Instrument}

To ensure content validity, the measures for the constructs are adapted from the existing literature. The appendix provides definitions of these constructs and key-related literature. Brand trust is measured using four items adapted from (Akrout \& Nagy, 2018); items for perceived social technology fit from Lu and Yang (2014); items for perceived brand experience from Biçakcioğlu et al. (2018); and items for social commerce engagement from Shen et al. (2019). The survey instrument consists of 12 items using a seven-point Likert scale ranging from "strongly disagree" to "strongly agree." The population is the users of several WeChat brand group. Invitations to take the survey were administered online. Of those WeChat brand group members invited, 95 members volunteered and took the survey. There are 500 members in the WeChat brand group. The response rate is $19 \%$.

\section{DATA ANALYSIS}

\section{Data Collection}

The data was collected through an online survey. A survey hyperlink was placed on a WeChat brand group. Only those people who were in the WeChat brand group were targeted for survey. Respondents were awarded a red pack with small amount money (¥10) through WeChat Pay. The partial least square (PLS) and structural equation modeling are used to test our measurement model and research hypotheses. First, we use partial least squares (PLS) to calculate construct validity, reliability, and discriminant validity. As shown in Table 1 and 2, all average extracted variance (AVE) values are higher than the recommended level of 0.5 . The Cronbach's Alpha and composite reliability value of each construct are above the suggested threshold of 0.7 (Hair et al., 2016; Bagozzi, 1981). Discriminant validity is recognized by comparing correlations among the constructs with the square root of AVE (Table 2) 
Table 1. Measurement Model Reliability and Validity

\begin{tabular}{|c|c|c|c|}
\hline & $\begin{array}{l}\text { Scale } \\
\text { item }\end{array}$ & $\begin{array}{l}\text { Standardized } \\
\text { loadings }\end{array}$ & $\begin{array}{l}\text { Composite } \\
\text { Reliability }\end{array}$ \\
\hline \multirow{4}{*}{ Brand Trust (BT) } & BT1 & 0.91 & \multirow[t]{4}{*}{0.79} \\
\hline & BT2 & 0.75 & \\
\hline & BT3 & 0.79 & \\
\hline & BT4 & 0.70 & \\
\hline \multirow{3}{*}{$\begin{array}{l}\text { Brand Experience } \\
\text { (BE) }\end{array}$} & BE1 & 0.67 & \multirow[t]{3}{*}{0.70} \\
\hline & BE2 & 0.73 & \\
\hline & BE3 & 0.70 & \\
\hline \multirow{3}{*}{$\begin{array}{l}\text { Social Technology Fit } \\
\text { (STF) }\end{array}$} & STF1 & 0.91 & \multirow[t]{3}{*}{0.92} \\
\hline & STF2 & 0.93 & \\
\hline & STF3 & 0.92 & \\
\hline \multirow{3}{*}{$\begin{array}{l}\text { Social Commerce } \\
\text { Engagement (SCE) }\end{array}$} & SCE1 & 0.72 & \multirow[t]{3}{*}{0.83} \\
\hline & SCE2 & 0.85 & \\
\hline & SCE3 & 0.91 & \\
\hline
\end{tabular}

Table 2. AVE and Discriminant Validity

\begin{tabular}{|l|l|l|l|l|l|}
\hline & AVE & BT & BE & STF & SCE \\
\hline BT & 0.58 & $\mathbf{0 . 7 6}$ & & & \\
\hline BE & 0.56 & 0.17 & $\mathbf{0 . 7 5}$ & & \\
\hline STE & 0.62 & 0.31 & 0.27 & $\mathbf{0 . 7 9}$ & \\
\hline SCE & 0.85 & 0.23 & 0.16 & 0.01 & $\mathbf{0 . 9 2}$ \\
\hline
\end{tabular}

\section{Mediation effect}

According to Zhao et al. (2010), it is a partial mediation effect if both direct and indirect effect from the one variable to another variable are significant; if the direct effect becomes less significant when the mediator is added, and the indirect effect is significant, there is a full mediation effect. The results of testing effects of the brand trust on social commerce engagement through social technology fit are presented in Table 3.

Results for the mediation analysis show that brand trust has significant $(\beta=0.332, p<0.05)$ direct effect on WECHAT social commerce engagement, and the indirect effect of brand trust on social commerce engagement through social technology fit is positive and significant $(\beta=0.426, \mathrm{p}<0.01)$, giving evidence of partial mediation. $\mathrm{H} 1$ is supported.

Table 3. Mediation Effect Results of Social Fit Technology

\begin{tabular}{|l|l|l|l|}
\hline Relationships & $\begin{array}{l}\text { Direct Effect without } \\
\text { Mediator }\end{array}$ & $\begin{array}{l}\text { Indirect Effect } \\
\text { with Mediator }\end{array}$ & $\begin{array}{l}\text { Mediation Type } \\
\text { Observed }\end{array}$ \\
\hline $\begin{array}{l}\mathrm{H}_{1}: \text { Brand Trust ->Social Technology } \\
\text { Fit- }>\text { Social Commerce Engagement }\end{array}$ & $\beta=0.332, \mathrm{p}<0.05$ & $\begin{array}{l}\beta=0.426, \mathrm{p}< \\
0.01\end{array}$ & Partial Mediation \\
& & & \\
\hline
\end{tabular}




\section{Issues in Information Systems}

Volume 20, Issue 3, pp. 158-164, 2019

\section{Moderation Effect Results}

The variable of brand experience is added to test the moderation. However, the beta coefficient indicates that at the model level, there is no significant difference to the relationship between the social technology fit and social commerce engagement ( $\beta=0.0135$; no significance). There is no significant moderation effect from brand experiences. $\mathrm{H} 2$ is not supported.

In summary, social technology fit partially mediates the effects of brand trust, and brand trust directly affects social commerce engagement. But, brand experience does not affect the relationship between social technology fit and social commerce engagement. These findings provide additional insights into WeChat social commerce research in WeChat brand groups.

\section{IMPLICATIONS AND LIMITATIONS}

This research makes several contributions to the field of social commerce: (1) we conceptualize WeChat social technology fit and study its mediation effects on social commerce engagement, which will be very useful for the further development of brand and social media research. The findings of this study also have important practical implications. We recommend that companies should consider the impact of technology fit of WeChat when they try to add social values of WeChat to their commercial values. For example, if a brand social representative joins their WeChat brand group, the sales representative can increase social ties and provides useful information about brand's products and services by using messaging, videos and pictures posts. To improve social technology fit of WeChat social commerce environment, a brand company should use WeChat different functions and features to build and strengthen relationships such as business subscription accounts, service accounts, and enterprise accounts. The WeChat official service account can detect user location. The technology will be fit for location-based brand marketing; WeChat enterprise account can also push new product introduction and promotions to its subscribers.

Future studies could explore the effects of other environmental issues on WeChat social commerce engagement. In fact, the participants in this study lack diversity. The size of the whole sample is significant. But, the group sizes might not be significant if the sample are split into two groups with low or high brand experiences. Since the group sample sizes may not be big enough and the average of brand experiences from the respondents is low, this study did not compare the moderation effects between groups of low brand experience and high brand experience. In addition, individual characteristics and different types of social technology would affect customers' social commerce performance. Future studies should consider a comparison of a WeChat brand group with those of other social media platforms. Further, a follow-up study on the impact of different cultures on social commerce engagement would be interesting in WeChat brand research.

\section{REFERENCES}

Animesh, A., Pinsonneault, S., Yang, B., \& Oh, W. (2011). An odyssey into virtual worlds: exploring the impacts of technological and spatial environments on intention to purchase virtual products, MIS Quarterly, 5(3), 789810 .

Akrout, H. \& Nagy, G. (2018). Trust and commitment within a virtual brand community: The mediating role of brand relationship quality. Information \& Management, 55(8), 939-955.

Bagozzi, R.P. (1981). Evaluating structural equation models with unobservable variables and measurement error: a comment. Journal of Marketing Research, 18(3), 375-381.

Bıçakcıoğlu, N., Ipek, İ, \& Bayraktaroğlu, G. (2018) Antecedents and outcomes of brand love: the mediating role of brand loyalty. Journal of Marketing Communications, 24(8), 863-877

Becerra, E. \& Badrinarayanan, V. (2013). The influence of brand trust and brand identification on brand evangelism. Journal of Product Brand Management, 22(5/6), 371-383. 
Brakus, J. J., Schmitt, B. H., \& Zarantonello, L. (2009). Brand Experience: What is It? How is It Measured?Does It Affect Loyalty? Journal of Marketing, 73(May 2009), 52-68.

Chaudhuri, A. \& Holbrook, M.B. (2001). The chain of effects from brand trust and brand affect to brand performance: the role of brand loyalty. Journal of Marketing, 65(4), 81-93.

De Vries, L., Gensler, S., \& Leeflang, P.S. (2012). Popularity of brand posts on brand fan pages: an investigation of the effects of social media marketing, Journal of Interactive Marketing, 26(2), 83-91.

Gu, L \& Wang, J. (2018). What May Affect Users to Sell, Buy, Or Swap on WECHAT? Issues in Information Systems, 19(2), 155-162.

Goodhue, D. \& Thompson, R. (1995). Task-Technology Fit and Individual Performance. MIS Quarterly, 19(2), 213236.

Ha, H.Y. \& Perks, H. (2005). Effects of consumer perceptions of brand experience on the web: brand familiarity satisfaction and brand trust. Journal of Consumer Behavior. 4(6), 438-452.

Hair, J. F., Black, W. C., Babin, B. J., Anderson, R. E., \& Tatham, R. L. (2006). Multivariate Data Analysis, New York: Pearson Education.

Islam, J.U. \& Rahman, Z. (2017). The impact of online brand community characteristics on customer engagement: an application of Stimulus-Organism-Response paradigm, Telematics and Informatics, 34(4), 96-109.

Leslie J., Emrich, O., Gupta, S., \& Norton, M. (2017). Does 'liking' lead to loving? The impact of joining a brand's social network on marketing outcomes. Journal of Marketing Research, 54(1), 144-155

Lu, H. \& Yang, Y. (2014). Toward an understanding of the behavioral intention to use a social networking site: An extension of task-technology fit to social. Computers in Human Behavior, 34(May 2014), 323-332

Macho, S. \& Ledermann, T. (2011) Estimating, testing, and comparing specific effects in structural equation models: the phantom model approach, Psychological Methods, 16(1), 34-43

Nahapiet, J., \& Ghoshal, S. (1998). Social capital, intellectual capital, and the organizational advantage. Academy of Management Review, 23(2), 242-266

Shen, X., Li, Y., Sun, Y., Chen, Z., \& Wang, F. (2019). Understanding the role of technology attractiveness in promoting social commerce engagement: Moderating effect of personal interest. Information \& Management, 56(4), 294-305

Tang, Z., Chen, L., \& Gillenson, M. (2018). Understanding brand fan page followers' discontinuance motivations: A mixed-method study. Information \& Management, 56(1), 94-108.

Wang, J \& Gu, L. (2017). Why is WeChat Pay so popular? Issues in Information Systems, 18(4), 1-8

Yang, H. (2013) A cross-cultural study of market mavens in social media: exploring young American and Chinese consumers' viral marketing attitudes, eWOM motives and behavior. International Journal of Internet Marketing and Advertising, 8(8), 102-124.

Zhang, K.Z., Barnes, S.J., Zhao, S.J., \& Zhang, H. (2017). Can consumers be persuaded on brand microblogs? An empirical study. Informant \& Management, 55(1), 1-15.

Zhang, H, Wang, Z., Chen, S., \& Guo, C. (2019). Product recommendation in online social networking communities: An Empirical Study of Antecedents and A Mediator. Information \& Management, 56(2), $185-195$. 
Zhao, X., Lynch, J.G., \& Chen, Q. (2010) Reconsidering Baron and Kenny: myths and truths about mediation analysis, Journal of Consumer Research, 37(2), 197-206.

\section{APPENDIX: SURVEY INSTRUMENT}

1.Social-technology fit (STF) (adapted from Lu \& Yang (2014))

STF1: In my opinions, WECHAT's functions are suitable for helping me complete my social situation Perceived Impacts

STF2: In my opinions, WECHAT's functions are enough to help me complete my social situation

STF3: In my opinions, WECHAT's functions are fit for the needs of my social situation

2.Social Commerce Engagement (SCE) (adapted from Shen et al., (2019))

SCE1: I am engaged in writing reviews in WeChat.

SCE2: I often participate in exchanging/buying/selling items through WeChat brand group.

SCE3: I frequently read review in WeChat

3. Brand trust (Akrout \& Nagy, 2018)

BT: I trust the product quality of this brand

BT2: Buying this brand's products is a safe bet.

BT3: This brand is sincere with consumers.

BT4: This brand is honest with consumers.

4. Brand experience (adapted from Biçakcıoğlu et al. (2018))

BE1: I find this brand interesting in a sensory way

BE2: This brand induces feelings and sentiments

BE3: I engage in physical actions and behaviors when I use this brand 